\title{
HOW TO MAKE YOUR MEDIEVAL RESEARCH MORE VISIBLE WITH OPEN SCHOLARSHIP METHODS AND TOOLS
}

\author{
Ulrike WuttKe ANd BJörn Gebert \\ Fachhochschule Postdam and Universität Münster \\ GERMANY
}

Date of receipt: $4^{\text {th }}$ of November, 2019

Date of acceptance: $17^{\text {th }}$ of February, 2020

\section{Abstract}

Today research is in the midst of a global transformation that is usually referred to as Open Science. Open Science is a response from communities to global societal developments and to the digital transformation of research processes and leads to the emergence of new practices that are embedded in a digital ecosystem. The global Medieval Studies community is slowly adapting to this new culture that raises new questions around scientific practices. This article discusses three major pillars of Open Science: Open Access, Open Data, and Open Science Communication in the Digital Age. It considers the potential of these practices for individual researchers and for the role of medieval research in a modern society and explains good practices to start with.

\section{KeYWORDS}

Open Scholarship, Open Access, Open Science, Medieval Studies, Scientific Communication.

\section{Capitalia Verba}

Academia aperta, Accessus apertus, Scientia aperta, Studia mediaevalia, Communicatio scientifica. 


\section{Introduction}

Have you ever struggled to obtain a publication available only in print in a library far away? Have you ever had to forego the idea of adding illustrations or pictures to your article because you could not afford the reproduction fees? Have you ever wondered how many people potentially would be interested in your research results and how many of them will actually be able to access them? With the enormous rise of the amount of researchers and publications and the possibilities of the Internet, you cannot just sit and wait for someone to discover your research. One way of broadening your scientific and societal impact is opening up the stages of your research process using Open Scholarship methods and tools. The more researchers, research institutions, and scholarly infrastructures are opening up scientific sources and results, the easier access becomes for everybody. This leads to a win-win situation and accelerates scientific research and impact in general.

Nowadays, critical citizens demand more understanding of the society they live in and the Humanities can proactively contribute to fulfilling this demand, but they need to seize the day and open up their research beyond the academic Ivory Tower. Although medievalists already apply Open Scholarship methods and tools (some good practice examples will be introduced below), their acceptance and implementation still varies greatly within Medieval Studies and the Humanities in general and depends on disciplinary cultures and national policies. ${ }^{1}$ Thus, while there is still need and space for the monograph, the edited volume, and the scientific article, it is important for medievalists to utilize the enormous potential of other channels to gain a broader societal impact for Medieval Studies and last, but not least, to prove their relevance against the backdrop of dwindling research budgets.

Against this backdrop, one of the authors of this article offered a workshop on Open Science during the 2018 annual meeting of CARMEN (The Worldwide Medieval Network) ${ }^{2}$ at Tampere University (Finland). ${ }^{3}$ The workshop under the title "How to make your medieval research more visible with Open Scholarship methods and tools" fitted perfectly within the annual meeting's general theme "Passages: Beyond the boundaries of Medieval Studies" as Open Science is all about

\footnotetext{
1. Tóth-Czifra, Erzsébet; Wuttke, Ulrike. “Loners, pathfinders, or explorers? How are the Humanities progressing in Open Science?". Generation R. 24 April 2019. Leibniz Research Alliance Open Science. 8 October 2019 <https://doi.org/10.25815/X516-wf23>.

2. CARMEN (The Worldwide Medieval Network). "About us". CARMEN. 21 July $2019<$ https://web. archive.org/web/20190721093235/http://www.carmen-medieval.net/cz/about-us-10039.html>. For reasons of safe citation, we have captured websites cited in this article via the Internet Archive Wayback Machine, wherever possible (some websites cannot be captured in this way for technical reasons). In these cases the URLs leading to time-stamped copies are provided. The live addresses of the original websites can be deduced from the second part of these links. We have not done this for content published online with a Persistent Identifier (for example a DOI), or in case of references to individual homepages of projects, institutions, etc.

3. For a workshop report and resources: Wuttke, Ulrike. “Let's talk about \#OpenScience (with a medieval touch)". Ulrike Wuttke. 3 September 2018. 21 July 2019 <https://web.archive.org/web/20190721093911/ https://ulrikewuttke.wordpress.com/2018/09/03/openscience-with-a-medieval-touch>.
} 
opening up research beyond boundaries. During the workshop an international group of medievalists vividly discussed the applicability, benefits and drawbacks of key concepts of Open Scholarship to Medieval Studies. This article takes up key points from the CARMEN workshop and places them into a broader perspective.

In the following, first, the Open Science movement and its key concepts will be introduced. Then, concrete good practice examples of how Open Scholarship methods and tools can be implemented into medieval research and publication practices and science communication will be discussed. Most of these examples do not require any advanced technological or coding skills. They focus especially on Open Access to scientific publications, including Open Data, and the Open Communication of scientific research activities and results via social media, blogging, videos, etc. The latter have an enormous potential to enhance research dissemination and the number of citations and are vital channels to communicate research results to nonspecialists. The article concludes with a summary of the discussion of challenges from the 2018 workshop and some take away messages" and an extensive list of key resources. It is our aim to contribute with this article to the promotion of Open Scholarship methods and tools among medievalists as they have intriguing stories to tell and public interest is almost assured if their outputs are "freed" from behind paywalls and "translated" for a non-specialist audience by using channels and formats beyond the traditional academic peer-to-peer discussion.

\section{What is Open Science-Open Scholarship?}

\subsection{Openness}

Open Access, Open Source, Open History, Open Science, Open Educational Resources, Open Content... all these more and more frequently used combinations with "Open" are part of a larger movement, maybe even a culture called Openness that encompasses many facets, values, and concepts. In the words of Felix Lohmeier and Jens Mittelbach: [...] Offenheit [ist] eine Kultur, die aus offenen Inhalten (Open Content), offenen Infrastrukturen (Open Infrastructure) und offenen wissenschaftlichen Prozessen (Open processes) gedeiht. ${ }^{4}$

Some of the facets of Openness, like Open Science and Open Access, have become quite independent movements of their own. Image 1 gives a good impression of the possibilities of the spectrum of Openness.

Openness is actually quite an old idea that can be linked to the emergence of the studium generale in the late Middle Ages: “This period highlights 'open' as learner driven, resting on a growing curiosity and increasing awareness of educational

4. "Openness is a culture, that flourishes through free content, open infrastructures and transparent scientific processes" (translated by Björn Gebert). Lohmeier, Felix; Mittelbach, Jens. "Offenheit statt Bündniszwang". Zeitschrift für Bibliothekswesen und Bibliographie, 61/4-5 (2014): 210-211. <http://dx.doi. org/10.3196/1864295014614554>. 


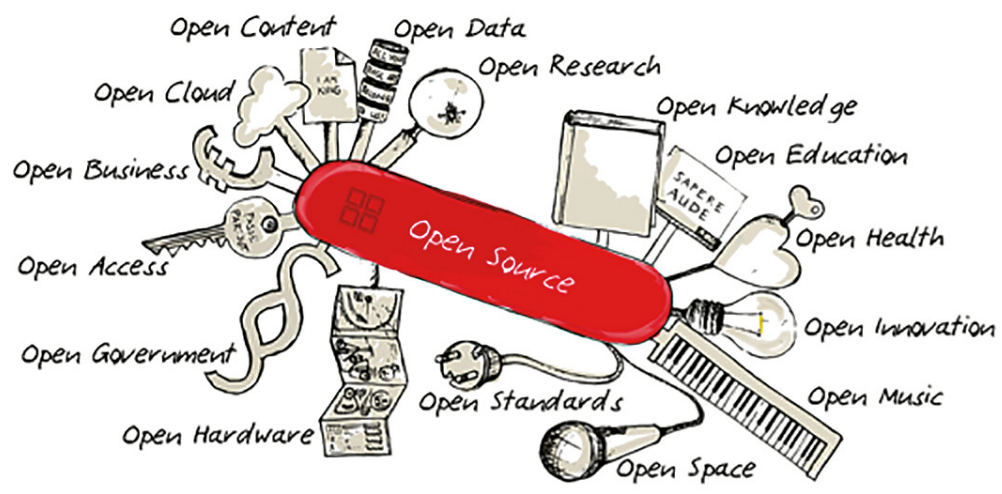

Illustration 1. Depiction of openness as a Swiss army Knife by Johannes Spielhagen/Open Source Business Foundation (Wikimedia Commons $<$ HTTPS://COMMONS.WIKIMEDIA.ORG/W/INDEX.PHP?CURID $=27179850>$, LICENSE

CC BY-SA 3.0).

opportunities. Scholars from all parts of the continent delivered lectures at no cost (for as long as knowledge was defined as a gift from God) and there was, to a large extent, an open curriculum, a preliminary form of an international institution." ${ }^{5}$ Openness could even be understood as one of the basic principles of the concept of the 'library' from antiquity on: the free or open access to information and thus knowledge. ${ }^{6}$ Thus, the recent rise of the culture of 'Openness' could be considered as a re-emergence of this old idea in a globalized and increasingly digitized world and society.

\subsection{Facets of Open Science}

There is no general acknowledged definition of 'Open Science'. Open Science may be best understood as an umbrella term for different practices aimed at making research more accessible and transparent. ${ }^{7}$ Although the most widely known Open Science movement is probably the Open Access movement (see 2.3), Open Science has many other facets, such as Open Data, Open Notebooks, Open Peer Review, Open Source, Scientific social networks, Citizen Science, Open Educational

\footnotetext{
5. Peter, Sandra; Deimann, Markus. "On the role of Openness in education: A historical reconstruction". Open Praxis, 5/1 (2013): 10. <http://dx.doi.org/10.5944/openpraxis.5.1.23>

6. Lohmeier, Felix; Mittelbach, Jens. "Offenheit...": 209-210. Although Lohmeier and Mittelbach have to admit that libraries were exclusively for the education of an elite until the end of the Middle Ages, they argue that Openness is a constitutional idea within the concept of libraries.

7. See Bueno de la Fuente, Gema. "What is Open Science? Introduction". FOSTER. 21 July 2019. <https://web.archive.org/web/20190721111901/https://www.fosteropenscience.eu/content/whatopen-science-introduction>.
} 
Resources etc. ${ }^{8}$ Pragmatically, one might say, Open Science is not a philosophy, but a set of practices.

It is unknown who coined the original term 'Open Science'. It seems to have developed along the general concept of 'Openness' (see 2.1). Nowadays, 'Open Science' is often used interchangeably with alternative terms such as 'Open Scholarship', 'Open Research', 'e-Science', and 'Science 2.0' that refer more or less to the same underlying idea of the transformation of scientific practice, but 'Open Science" is the most widespread term. ${ }^{9}$ Although 'Open Science' encompasses all fields of research, especially in the Anglo-American language area scholars from the Humanities often feel left out because 'Science' (unlike e.g. the German term 'Wissenschaft') does only apply to the Natural Sciences. They therefore prefer the term 'Open Scholarship'. In this article both terms are used to denote the paradigm change towards open and transparent principles in research and research dissemination.

\subsection{Open Access Terminology and Licenses}

\subsubsection{Definition: Open Access}

The term Open Access, created in the 1990s, has become quite common in the sciences and in the Humanities. ${ }^{10}$ It is used to denote different kinds of publications that are freely available. However, it is necessary to underline that Open Access refers to a specific kind of free availability. According to the most important Open Access declaration, the "Berlin Declaration on Open Access to Knowledge in the Sciences and Humanities" (2003), ${ }^{11}$ Open Access demands that right holders grant certain rights to all users:

Open access contributions must satisfy two conditions: The author(s) and right holder(s) of such contributions grant(s) to all users a free, irrevocable, worldwide, right of access to, and a license to copy, use, distribute, transmit and display the work publicly and to make and distribute derivative works, in any digital medium for any responsible purpose, subject to proper attribution of authorship (community standards, will continue to provide the mechanism for enforcement of proper attribution and responsible use of the published work,

\footnotetext{
8. Bueno de la Fuente, Gema. "What is...".

9. Bueno de la Fuente, Gema. "What is...".

10. The most seminal book on Open Access is Suber, Peter. Open Access. Cambridge (Mass.)-London: Massachusetts Institute of Technology Press, 2012. The book is available Open Access, also in several languages besides the original English. A discipline-specific discussion of the topic offers is Eve, Martin Paul. Open Access in the Humanities. Contexts, controversies and the future. Cambridge: Cambridge University Press, 2014. Also this book is available Open Access.

11. "Berlin Declaration on Open Access to Knowledge in the Sciences and Humanities". Max-PlanckGesellschaft. 22 October 2003. 21 July 2019 <https://web.archive.org/web/20190721115052/https:// openaccess.mpg.de/Berliner-Erklaerung $>$. The Berlin Declaration gains its importance from its more than 600 international signatories (universities, research foundations, academies, and scientific societies).
} 
as they do now), as well as the right to make small numbers of printed copies for their personal use. ${ }^{12}$

According to this definition, a published work does not only have to be available freely to be considered Open Access, but also further usage rights have to be granted by the application of a 'free' license to a work - 'free' because the granted uses exceed those normally granted by copyright.

\subsubsection{Creative Commons Licenses: Open Access, more than 'Freely Online'}

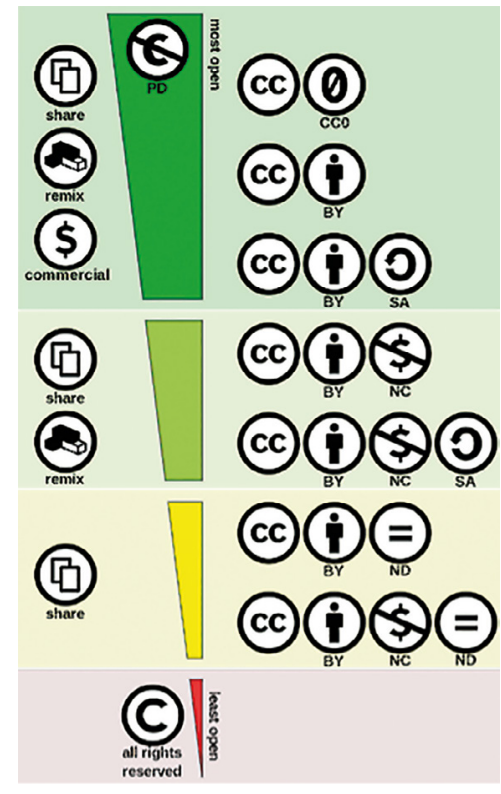

Illustration 2. Creative Commons LICENSE SPECTRUM. IMAGE PROVIDED BY USER "SHADDIM". (WIKIMEDIA COMMONS <HTTPS://COMMONS. WIKIMEDIA.ORG/WIKI/FILE:CREATIVE_ COMMONS_LICENSE_SPECTRUM.SVG $>$, LICENSE CC BY 4.0).
The most common 'free' licensing system for text publications is the Creative Commons (CC) License Spectrum, a modular licensing system, where the modules BY (Attribution), SA (ShareAlike), NC (NonCommercial), and ND (NonDerivatives) can be combined. ${ }^{13}$ Image 2 shows possible combinations of CC licenses.

A freely available online publication is per se an advantage for all interested readers compared to a closed access publication behind a pay wall -and can thus reach a larger audience. Nevertheless, there are good reasons, why not every freely available online publication is considered Open Access. Open Access as a label grants users of a published work further rights, such as the right to distribute the licensed work again, making it thus available to an even larger audience and helping to ensure the preservation and long-term availability. ${ }^{14}$

Another right required by the Berlin declaration is the right to "make and distribute derivative works", ${ }^{15}$ meaning that users should be allowed to remix or build upon published works, for instance by using parts of licensed works or even complete works, and combine them with (parts of) other works or new parts in order to create a new work. This right is not

12. "Berlin Declaration...".

13. "Creative Commons licenses". Creative Commons. 21 July $2019<$ https://web.archive.org/ web/20190721 120407/https://creativecommons.org/share-your-work/licensing-types-examples>.

14. LOCKSS (Lots Of Copies Keep Stuff Safe) is an example of a long-term preservation project based on Open Access rights. LOCKSS. Stanford University. 6 October $2019<$ https://www.lockss.org>.

15. "Berlin Declaration...". 
granted to users by using ND restrictions, such as in CC BY-ND or CC BY-NC-ND licenses. ${ }^{16}$ The NC module, forbidding any commercial usage, can also be problematic. For example, it may not be possible to include an NC-licensed article in a print publication (unless the print publication is made available for free) or to combine BY-NC content with BY-SA content. Additionally, an NC restriction prohibits the distribution in the context of some educational uses, e.g. where course fees are applicable. Also, the Wikimedia Foundation ${ }^{17}$ and other platforms committed to different definitions than the Berlin Declaration - the Open Definition ${ }^{18}$ and the Definition of Free Cultural Works- ${ }^{19}$ do not allow the application of NC or ND licenses to uploads. ${ }^{20}$ Thus, while all CC licenses grant more rights to the users than traditional copyright, not all of them can be considered Open Access according to the Berlin Declaration.

Only the three licenses in the dark green area in the upper part of image 2 fulfill the requirements of the Berlin Declaration: CC BY and CC BY-SA, because they grant the users all rights required by the definition, while a third one, CCO (=Public Domain Dedication), grants even more rights. ${ }^{21}$ But while this last license does not explicitly demand proper attribution by the user, proper attribution should be good academic practice anyway. So, as harsh as it may appear to hold on to the letter of the Berlin Declaration, when it comes to declaring whether a work is or is not Open Access, there are good reasons for the extensive demands of Openness within this definition. And thus there are good reasons why the authors recommend the application of CC BY, CC BY-SA or CCO licenses, if possible: to enable maximum distribution, reusability, and thus maximum impact of a published work. ${ }^{22}$

16. "About the licenses". Creative Commons. 6 October 2019 <https://web.archive.org/ web/20191006102324/https://creativecommons.org/licenses/?lang=en>.

17. “Commons: Licensing”. Wikimedia Commons. 7 August 2019. Wikimedia Foundation. 6 October $2019<$ https:// web.archive.org/web/20191006103134/https://commons.wikimedia.org/wiki/Commons:Licensing/en>.

18. “Open Definition. Version 2.1". Open Definition. Open Knowledge Foundation. 6 October 2019 <https://web.archive.org/web/20191006103258/http://opendefinition.org/od/2.1/en>.

19. "Definition. Version 1.1". Free Definition of Cultural Works. 17 February 2015. 6 October $2019<$ https:// web.archive.org/web/20191006103715/https://freedomdefined.org/Definition>.

20. An interpretation of the NC module for Creative Commons licenses: "NonCommercial interpretation". Creative Commons. 15 October 2017. 6 October 2019 <https://web.archive.org/web/20191006104110/ https://wiki.creativecommons.org/wiki/NonCommercial_interpretation>.

21. "Lizenzen". Open-Access.net. Freie Universität Berlin-Universität Göttingen-Universität KonstanzUniversität Bielefeld. 5 October 2019 <https://web.archive.org/web/20191005150952/https://openaccess.net/informationen-zu-open-access/rechtsfragen/rechtsfragen-in-deutschland/lizenzen>.

22. For a different view see: Hausmann, Albrecht. "Wissenschaftsnahes Publizieren im digitalen Zeitalter". Beiträge zur mediävistischen Erzählforschung, 2 (2019): 2-11. The logic in defending the choice of the comparatively rigid CC BY-NC-ND license is, however, at least partially flawed: the fear that a CC BY license requires for proper attribution only the name of the author while the context of the original publication like the journal and issue were not required (see pages 8-9), is ungrounded, because the license requires much more details than only the name of the author - among others a link to the original material, all attribution parties and even an indication, whether the original material was modified. "License versions", Creative Commons. 4 January 2016. 5 October $2019<$ https://web.archive. org/web/20191005151338/https://wiki.creativecommons.org/wiki/License_Version>. 


\subsubsection{The Open Access Spectrum (Gold, Green, Diamond, Bronze, Hybrid)}

Given the requirements of the major definition of Open Access are met by the application of a suitable license to the work in question, there are still different kinds of Open Access — or "roads". The most common roads are Gold and Green Open Access, but the Diamond (or Platinum) Road is becoming increasingly important and there is also a Bronze and a Hybrid Road. Because the terminology can be a bit confusing, these roads are shortly explained in the following.

- Gold Open Access. The Golden Road to Open Access usually means a primary publication of a work that has passed a community standard quality assurance process, under an Open Access compatible license, with an Article Processing Charge (APC) to be paid by the author(s) to the commercial publisher of the journal or book for the publication of the article..$^{23}$

- Green Open Access. The Green Road to Open Access means that a work that was previously published in Closed Access and has thus passed a community standard quality assurance process is republished under an Open Access compatible license, usually via self-archiving by the author on a repository. ${ }^{24}$ While it is also possible that an article that has originally been published in Closed Access can be "freed" afterwards by paying a fee to the publisher, it is more common that the article can automatically be republished (or 'self-archived') by its author(s) after a certain period (usually after a 'moving wall' of one or several years)..$^{25}$ Preprints made available by an author -without having been accepted for a refereed journal yet, are also considered Green Open Access. So not every Green Open Access publication has undergone a quality assurance process, although many did.

- Diamond Open Access. The Diamond or Platinum Road to Open Access refers to a primary publication that has passed a community standard quality assurance process, under an Open Access compatible license, in a community driven journal or on a community driven platform without or with only a minor publication fee. ${ }^{26}$ This new approach to Open Access is on the rise lately as a reaction to the surging APCs of some commercial publishers.

23. “Open Access strategies”, Open-Access.net. Freie Universität Berlin-Universität Göttingen-Universität Konstanz-Universität Bielefeld 6 October 2019 <https://web.archive.org/web/20191005151801/https://openaccess.net/en/information-on-open-access/open-access-strategies $>$. See also Suber, Peter. Open...: 52-58.

24. "Open Access Strat...".

25. For a helpful list of publishers' policies regarding moving walls and self-archiving rights SHERPA/ RoMEO, see Sherpa Romeo. Jisc. 6 October 2019 <http://sherpa.ac.uk/romeo/index.php>.

26. Harrington, Robert. "Diamond Open Access, societies and mission". The Scholarly Kitchen, 1 June 2017. Society for Scholarly Publishing. 21 July $2019<$ https://web.archive.org/web/20190721135653/ https://scholarlykitchen.sspnet.org/2017/06/01/diamond-open-access-societies-mission>; Poynder, Richard. "The Open Access interviews: Sir Timothy Gowers, mathematician". Richard Poynder. 20 April 2016. 8 March 2020 <https://web.archive.org/web/20200308133505/https://richardpoynder.co.uk/ Timothy_Gowers.pdf>; Fuchs, Christian; Sandoval, Marisol. “The Diamond Model of Open Access publishing: Why policy makers, scholars, universities, libraries, labour unions and the publishing world need to take non-commercial, non-profit Open Access serious". Triple, $11 / 2$ (2013): 428-443. <http:// doi.org/10.31269/triplec.v1 1i2.502>. 
Sometimes the term Gold Open Access or non-APC Gold Open Access is applied to such publications. While this is - generally speaking - not wrong, it makes a crucial difference whether or not you have to pay an APC of several hundreds or thousands of Euros or Dollars to a commercial publisher. Hence, the term Diamond Open Access was introduced, to differentiate between APC and non-APC based primary Open Access publication models.

It must be noted that the term 'Diamond' or 'Platinum Open Access' seems to imply a higher value or higher standard than 'Gold Open Access', while it is hard to say why 'Green Open Access' is not called 'Silver Open Access'. This choice of terminology could be justified by the fact that a noncommercial, low cost, community driven publication model is most comfortable for authors and thus the best way to motivate researchers to publish online in Open Access.

- Bronze Open Access. 'Bronze Open Access' is a rather uncommon term although it could be used for a vast amount of articles. Bronze Open Access refers to works that are published online and can be accessed freely, but lack an Open Access compatible license or any clear license at all, thus leaving potential users in doubt about the terms of reuse. ${ }^{27}$ However, it is questionable whether the term 'Open Access' should be applied at all to works that clearly are not, according to the Berlin Declaration.

- Hybrid Open Access. The term 'Hybrid Open Access' refers to articles (primary publications) that are published with Open Access compatible licenses in otherwise Closed Access journals. These articles are usually 'freed' by paying APCs. This means that while only subscribers of Closed Access journals can access all content, those hybrid articles are 'unpaywalled' for everyone. However, Hybrid Open Access has raised some concern as it is considered as 'double dipping', meaning that publishers are paid twice for one article. Therefore, it is often harder (or impossible) to get funding for the APCs. ${ }^{28}$

\section{Why Open Science (is good for you)?}

While researchers and science funders may highlight different reasons to underpin the demand of Open Science, the most common sense argument for Open Science is probably that scientific knowledge is a product of social collaboration. Researchers are in general paid to conduct research; therefore, it seems logical that its ownership should belong to the community. Additionally, during the

\footnotetext{
27. Piwowar, Heather; Priem, Jason; Larivière, Vincent; Alperin, Juan Pablo; Matthias, Lisa; Norlander, Bree; Farley, Ashley; West, Jevin; Haustein, Stefanie. "The state of OA: A large-scale analysis of the prevalence and impact of Open Access articles". PeerJ. 13 February 2018. 8 October 2019 <https://doi. org/10.7717/peerj.4375>.

28. "Business models". Open-Access.net. Freie Universität Berlin-Universität Göttingen-Universität Konstanz-Universität Bielefeld. 5 October 2019 <https://web.archive.org/web/20191005153506/https:// open-access.net/en/information-on-open-access/business-models $>$.
} 
last years, the rapid digital transformation of research has accelerated the Open Science movement, making research workflows more collaborative, international, and inclusive, including citizens demanding access to scientific research results and actively participating in research themselves. ${ }^{29}$ More specifically, Open Access and Open Data are basic requirements for computational approaches such as the Digital Humanities. Without Open Access and Open Data, there are, to put it simply, no data to work with. If we let commercial publishers dictate digital publication structures and requirements, we rob ourselves as a community of the possibility to publish according to the community's needs, which are increasingly characterized by paradigms such as datafication and machine actionability.

The European Commission has brought these developments together in a Open science and innovation vision for Europe under the title Open Innovation, Open Science, Open to the world - A vision for Europe ${ }^{30}$ and formulated as its goal the development of the European Open Science Cloud (EOSC) $)^{31}$ that will provide Open Access to scientific data. Along its implementation phase (2018-2020), the EOSC roadmap is set for the implementation of open practices and especially the FAIR data principles ${ }^{32}$ that will set the pace for changes in the practice and culture of research. However, Open Science is not a European, but a global movement (though the perspective of the authors of this article is admittedly European). Initiatives like, for example, cOAlition $\mathrm{S}^{33}$ an international consortium of research funders to accelerate the transformation to Open Access publishing (Plan S), have found supporters far beyond Europe. ${ }^{34}$

Open Science also has substantial advantages for researchers themselves, especially their research quality and visibility. In general, adopting Open Science workflows, tools, and methods can lead to a higher reproducibility of research

29. For a comprehensive introduction into Citizen Science, its potentials and practical aspects, see Hecker, Susanne; Haklay, Muki; Bowser, Anne; Makuch, Zen; Vogel, Johannes; Bonn, Aletta, eds. Citizen Science: Innovation in Open Science, society and policy. London: University College London Press, 2018. This book is available Open Access.

30. Open Innovation, Open Science, Open to the world. A vision for Europe. Brussels: Directorate-General for Research and Innovation, 2016 (available in <https://ec.europa.eu/digital-single-market/en/news/openinnovation-open-science-open-world-vision-europe $>$ ).

31. Prompting an EOSC in practice. Final report and recommendations of the Commission 2nd High Level Expert Group [2017-2018] on the European Open Science Cloud (EOSC). Brussels: Directorate-General for Research and Innovation, 2018 (available in <https://publications.europa.eu/s/mwdM>).

32. "FAIR principles". Go FAIR. 22 July 2019 <https://web.archive.org/web/20190722075542/https:// Www.go-fair.org/fair-principles $>$.

33. Website: <https://www.coalition-s.org>.

34. For a perspective on Plan S from Latin America and the Global South, see Becerril-García, Arianna. "AmeliCA vs Plan S: Same target, two different strategies to achieve Open Access". Ameli Blog. 10 February 2019. AmeliCA. 22 July 2019 <https://web.archive.org/web/20190722082744/http://www.amelica.org/ en/index.php/2019/01/10/amelica-vs-plan-s-mismo-objetivo-dos-estrategias-distintas-para-lograr-elacceso-abierto/>. For a perspective on Plan S from humanities publishing, see Lange, Jasmin. "Plan S and humanities publishing". The Scholarly Kitchen, 2 July 2019. Society for Scholarly Publishing. 22 July 2019 <https://web.archive.org/web/20190722083224/https://scholarlykitchen.sspnet.org/2019/07/02/ guest-post-plan-s-and-humanities-publishing/?informz=l>. 
findings, higher transparency of research methods and evaluation, higher team effectiveness, and higher sustainability of your research, thus saving researchers and research institutions alike money and time. Speaking more of advantages for individual researchers, or what one may call 'selfish reasons' for Open Science, there are indicators that Open Research practices also have substantial benefits for individuals, e.g. a higher societal impact of researchers and research results by getting more citations because of open publications, increasing chances for research collaborations, better job opportunities and funding opportunities as open research practices become standard and are included in job descriptions and funding requirements, or even media attention. ${ }^{35}$ Last but not least, open research practices can also be considered as an ethical choice: choosing to be as open as possible and thus standing in for ethical ideals seems a sensible thing to do.

There are many shades of Open Science; therefore for every individual researcher Open Science will look differently in practice as concrete practices are shaped by individual and disciplinary factors and circumstances. It increasingly becomes acknowledged that the Humanities have different publication, research, and communication practices and tools compared to STEM (Science, Technology, Engineering and Medicine), that need to be included in the Open Science discussion. ${ }^{36}$

Practicing Open Science requires individual researchers to analyze their workflows and to start to open up those practices and traditions that favor secrecy and closeness wherever possible. It does neither require all medievalists to become data wizards, nor to work fully in the open all the time as will become clear from the following good practice examples.

\section{Good Practice Examples}

At the center of open practices is Open Access to research output, meaning online (peer-reviewed) scholarly output (mainly articles and monographs) that is free to read and with limited or no copyright or licensing restrictions (see 2.3.1). Recently also alternative forms of research outputs such as research data, teaching materials such as tutorials or presentation slides (often referred to as 'Open Educational Resources', short OER) ${ }^{37}$ and other forms of scientific communication that evoke different aspects, methods, and tools have come under attention. The DORA

\footnotetext{
35. McKiernan, Erin C.; Bourne, Philip E.; Brown, C. Titus; Buck, Stuart; Kenall, Amye; Lin, Jennifer; McDougall, Damon, Nosek, Brian A.; Ram, Karthik; Soderberg, Courtney K.; Spies, Jeffrey R.; Thaney, Kaitlin; Updegrove, Andrew; Woo, Kara H., Yarkoni, Tal. "How Open Science helps researchers succeed". eLife. 7 July 2016. 8 October 2019 <http://doi.org/10.7554/eLife.16800>.

36. For example Giglia, Elena. “OPERAS: Bringing the long tail of Social Sciences and Humanities into Open Science". JLIS.it, 10/1 (2019): 140-156. <http://dx.doi.org/10.4403/jlis.it-12523>.

37. "Open Educational Resources (OER)". United Nations Educational, Scientific and Cultural Organization. 26 July 2019 <https://web.archive.org/web/20190726105637/https://en.unesco.org/themes/buildingknowledge-societies/oer $>$.
} 
declaration for example recommends giving credit for more than only articles, for example also for data sets and software. ${ }^{38}$ In the following section, key open practices are illustrated from a Medieval Studies point of view.

\subsection{Open Access Publishing}

As already outlined above (see 2.3.1) Open Access according to the Berlin Declaration requires using a free license. It also requires storing the publication in an Open Access repository (see below). This means that using Academia.edu or ResearchGate to upload content does not fulfill the Open Access requirements of the Berlin Declaration and of many institutional or funder policies. These services are not Open Access repositories, but commercial services that thrive on selling additional services and promoting ads to their members or even worse selling their members' data, and do not guarantee long-term preservation. ${ }^{39}$

Receiving credit for online publications is supported by ORCID (Open Researcher and Contributor ID). ${ }^{40}$ Getting an ORCID takes only a few minutes, and having a persistent identifier that distinguishes you from others - different versions of your name (like your given name in full or only by initial) included- and can be integrated into various research workflows, will tremendously enhance the linking of your various research outputs with your scholarly record. You can even use your ORCID profile as an online CV.

\subsubsection{Articles and Books}

When it comes to the Open Access publication of articles and books, there are mainly two possibilities: 1) to publish directly Open Access or 2) to legally deposit (self-archive) a copy of an originally Closed Access publication as Green Open Access (see 2.3.3).

Concerning journal articles, there is an increasing number of e-journals available for medievalists. However, many of them cannot be considered Open Access according to the Berlin Declaration and some commercial Open Access journals ask from the authors considerable APCs while in other often community driven journals authors can publish for free or at a low price (see above 2.3.3). ${ }^{41}$ Therefore,

\footnotetext{
38. "San Francisco Declaration on Research Assessment". DORA. 26 July 2019 <https://web.archive.org/ web/20190726110115/https://sfdora.org/read>.

39. Fortney, Katie; Gonder, Justin. "A social network is not an Open Access repository". Office of Scholarly Communication. University of California. 1 December 2015. 26 July 2019 <https://web.archive.org/ web/201907261 10415/https://osc.universityofcalifornia.edu/2015/12/a-social-networking-site-is-notan-open-access-repository>.

40. Website: <https://orcid.org>.

41. Gebert, Björn. "Soll ich oder soll ich nicht? 10 Gründe, warum es sich für Historiker*innen lohnt zu bloggen". Zeitarbeit, 1 (2019): 42-43. <http://doi.org/10.25521/ztbt.2019.92>.
} 
it is worth to check the licensing policy and publication costs of the journal that you are considering for your publication, before making a final decision.

Lately so-called predatory journals have come into the spotlight. Their business model is based on pseudo-serious journals with fake advisory boards and fake peer review under an Open License, thus discrediting Open Access. ${ }^{42}$ In order to find a trustworthy scholarly Open Access journal in your area of research you can use the Directory of Open Access Journals (DOAJ). As not all academic journals are (yet) included into DOAJ, an alternative way to assess the trustworthiness of a journal is provided by the "Think.Check.Submit" initiative. ${ }^{43}$

Two interesting initiatives we would especially like to highlight here are the Open Library of Humanities (OLH) ${ }^{44}$ and OpenEdition. ${ }^{45}$ OLH offers a variety of journals and has based its publishing model on a non-commercial approach, meaning it is mainly financed via library subscriptions and free for authors. OpenEdition brings together platforms for electronic Open Access journals, books, blogs, and events announcements.

If it proves to be difficult to find a good Open Access journal in your research field, this may indicate a gap. If you are a bit adventurous, you could consider closing this gap by founding a new Open Access journal. To serve this need, more and more universities or university libraries provide a journal hosting service that can be deployed for Open Access Journals. Often this service is based on OJS (Open Journal Systems). ${ }^{46}$ This Open Source software is very easy to manage for editors, it allows assigning Digital Object Identifiers (DOIs) to all articles, and it can be connected with an infrastructure for digital long-term preservation.

When it comes to Open Access publishing of books, by now many commercial publishers also offer Open Access options for books, but often with an expensive price tag attached. Therefore, it is worthwhile to check other options such as University Presses and other —often community driven- presses that are dedicated to promoting Open Access to books. Regarding to a common concern, Open Access book publication does not require a solely digital publication; it is often possible to publish a print and a digital version at the same time. ${ }^{47}$ Also, a recent study has shown that academic books that are published Open Access reach more readers and are cited around 10\% more often while the availability of the Open Access version has no mentionable effect (neither positive nor negative) on the sale of the print

42. Nahl, Jan Alexander van. "The robber barons of Open Access publishing". Mittelalter. Interdisziplinäre Forschung und Rezeptionsgeschichte. 16 June 2015. 26 July 2019 <https://web.archive.org/ web/20190726110739/https://mittelalter.hypotheses.org/6260>.

43. Website: <https://thinkchecksubmit.org>.

44. Website: <https://www.openlibhums.org>.

45. Website: <https://www.openedition.org>.

46. Website: <https://pkp.sfu.ca/ojs>. The same company also offers Open Monograph Press, an Open Source platform for e-book publication. Website: <https://pkp.sfu.ca/omp >.

47. For a discussion of challenges and perspectives of digital scholarly monographs in the humanities, see Kuhn, Axel; Hagenhoff, Svenja. “Nicht geeignet oder nur unzureichend gestaltet? Digitale Monographien in den Geisteswissenschaften“. Zeitschrift für digitale Geisteswissenschaften, 5 (2019). 8 October $2019<$ http:// dx.doi.org/10.17175/2019_002>. 
edition. ${ }^{48}$ Lately consortia like HIRMEOS ${ }^{49}$ have done much work to promote Open Access to research monographs and worked on technical standards, frameworks, and services.

You can search for Open Access books via the Directory of Open Access Books $(\mathrm{DOAB}),{ }^{50}$ other special tools dedicated to unearthing Open Access publications (not only books) are BASE, ${ }^{51}$ ISIDORE $^{52}$ and Unpaywall. ${ }^{53}$ BASE is a search engine for Open Access publications that is connected to Open Knowledge Maps, ${ }^{54}$ an innovative visualization of the BASE content. ISIDORE is a search engine for digital data dedicated to the Humanities and Social Sciences that assigns also persistent identifiers to each indexed resource. Unpaywall is a popular browser extension that shows you immediately if an Open Access version of an article exists.

\subsubsection{Academic Blogs}

Blogs in general were invented in the 1990s, starting as fashion blogs, food blogs, or simply as personal (in the internet not so private, though) online diaries. Hence the name: blog is the abbreviation of weblog, a compound of web and log (like in logbook). About 20 years ago, academics adopted and adapted blogs for academic purposes. ${ }^{55}$

Today academic blogs are a widespread phenomenon in the Humanities and specifically in Medieval Studies. There are at least dozens of blogs that focus on the Middle Ages: blogs by individual researchers, groups of researchers, and institutions. There are blogs that focus on one or some aspects of the Middle Ages (e.g. Howard Williams's blog Archaeodeath. The archaeology and heritage of death $\theta$ memory), ${ }^{56}$ a research project (e.g. Charles West's blog Turbulent Priests, a project blog), ${ }^{57}$ a (sub-) discipline (e.g. Maxi Maria Platz's medieval archeology blog MinusEinsEbene. Ein mittelalterarchäologisches Blog), ${ }^{58}$ one or several auxiliary science(s) (e.g. the blog Heraldica nova. Medieval and early modern heraldry from the perspective of Cultural History

48. Snijder, Ronald. The deliverance of Open Access books: Examining usage and dissemination. Leiden: Leiden University (PhD Dissertation), 2019.

49. Website: <https://www.hirmeos.eu>.

50. Website: <https://www.doabooks.org >.

51. Website: <https://www.base-search.net>.

52. Website: <https://isidore.science $>$.

53. Website: <https://unpaywall.org $>$.

54. Website: <https://openknowledgemaps.org>.

55. König, Mareike. “Wissenschaftliche Blogs zwischen Deutschland und Frankreich: die Blogplattform Hypotheses.org", France-Allemagne au XXe siècle. La production de savoir sur l'autre. IV: Les médias, Michel Grunewald, Hans-Jürgen Lüsebrink, Reiner Marcowitz, Uwe Puschner, eds. Bern-Berlin-BruxellesFrankfurt-New York-Oxford-Wien: Peter Lang, 2014: 241-255.

56. Website: <https://howardwilliamsblog.wordpress.com>.

57. Website: <http://turbulentpriests.group.shef.ac.uk>.

58. Website: <https://minuseinsebene.hypotheses.org>. 
edited by the project 'Die Performanz der Wappen (Dilthey-Fellowship)'), ${ }^{59}$ or on the Middle Ages plus the history of their reception in general (e.g. the blog edited by Martin Bauch, Karoline Döring, and Björn Gebert Mittelalter. Interdisziplinäre Rezeptionsgeschichte).$^{60}$ In the left column of the latter is a 'medieval blogroll', listing almost 100 blogs.

The most common software for blogs is WordPress, ${ }^{61}$ an Open Source content management system (or weblog publishing system). While some researchers have their blog hosted by general blog farms like wordpress.com, other academic blogs are hosted by universities. But there are also dedicated academic blogging platforms for the Humanities and Social Sciences such as Hypotheses. ${ }^{62}$ Hypotheses was founded in France in 2009 and has several 'daughters' for different languages: French, English, German and Spanish. It offers free, preconfigured blogs for scholars - currently almost 3.000 blogs are listed in the Hypotheses catalogue, meaning they have steadily published solid content for several weeks after their creation.

Blogs have advantages compared to normal, static websites, like the automatic display of the latest article on top of the blog. This together with the possibility to easily comment on individual blogposts and to start a discussion, or the simple way of sharing blogposts in social networks, have made academic blogs an alternative way of scholarly publishing. An example for an academic blog that has become a popular platform even for Open Access publications in the field of Medieval Studies is Mittelalter. Interdisziplinäre Forschung und Rezeptionsgeschichte (Mittelalterblog). ${ }^{63}$

Since its foundation in late 2012, the editors/publishers of Mittelalterblog had the following intention:

Ziel ist der interdisziplinäre wissenschaftliche Austausch, die Vernetzung von Mediävisten, vor allem die Vernetzung des wissenschaftlichen Nachwuchses, die Veröffentlichung von fachrelevanten Informationen und Terminen und auch, im Sinne einer wissenschaftlichen Vermittlung des Mittelalters, die Publikation von Forschungsergebnissen im Open Access. ${ }^{64}$

Today, Mittelalterblog reaches between roughly 8.500 and 15.000 unique visitors per month, ${ }^{65}$ and more than 500 blog posts by more than 150 authors (mostly PhD candidates or Postdocs) from at least 10 different countries have been published

59. Website: <https://heraldica.hypotheses.org>.

60. Website: <https://mittelalter.hypotheses.org $>$.

61. Website: <https://wordpress.com>.

62. Website: <https://hypotheses.org >.

63. See note 60 .

64. "The aim is interdisciplinary exchange, networking for medievalists, especially for junior researchers, the publication of relevant information and dates in the field of medieval studies, and also, with the aim of communicating research on the middle ages, the publication of research results in Open Access" Bauch, Martin; Döring, Karoline; Gebert, Björn. “Mitlesen-Mitbloggen!”. Mittelalter. Interdisziplinäre Forschung und Rezeptionsgeschichte. 14 February 2013. 29 July 2019. <https://web.archive.org/web/20190729141408/ https://mittelalter.hypotheses.org/488>. Translation by Björn Gebert.

65. Survey period 1 June 2018 to 31 May 2019. The statistics of the blog are openly accessible in <https:// logs.openedition.org/awstats.pl?config=mittelalterhypothesesorg $>$. 
on the blog. More than 150 of these 500 blog posts are scholarly articles (primary publications) - that means an author must hold at least a Master's degree (or an equivalent: Magister, Staatsexamen, Diplom) and at least two blog editors or external reviewers review each article. All articles have an html/blog version and a PDF/A version (a format suitable for long-term preservation) and are recorded in the RI Opac, ${ }^{66}$ the major literature database for the Middle Ages that currently lists over 2.3 million titles. The RI Opac is provided by the project Regesta Imperii that is based mainly at the Academy of Sciences and Literature in Mainz.

There are two major differences between e-journals and blogs. First, blogs publish ad hoc or dynamically, their publication rhythm is not restricted to one or more issues each year. Secondly, unlike journals, blogs enable direct discussions between authors and readers, mostly via direct commenting functions below blog posts/articles. The dynamic release of contents in a blog offers the possibility to publish also proceedings or edited volumes in general, in a dynamic way. ${ }^{67}$ To give an example, in 2018 Mittelalterblog published the proceedings of a workshop held in Trier in November 2017 as its first Beiheft (supplement series). First, all articles of the Beiheft were published successively from May to November 2018, each one as a blog/html version and as a PDF/A version with continuous page numbers. Finally, a PDF/A version of the entire volume, consisting of the already published individual articles plus two prefaces (one from the editors of the individual volume and one from the general editors of the Beihefte series), title page, contents, and short biographies of the authors and volume editors, was published on the blog. ${ }^{68}$

While previously blog articles in contrast to journal articles did not have Persistent Identifiers (such as DOIs, URNs or handles), even that is changing. The French search engine ISIDORE assigns handle identifiers to all blog articles it harvests and on September $25^{\text {th }} 2019$, the first scholarly article on Mittelalterblog was assigned a DOI. ${ }^{69}$ The long-term preservation of blog posts works in the same way as for many e-journals: If a blog post is published as a html/blog version and as a PDF/A version, the latter can be archived in a repository (in the case of Mittelalterblog, the long-term preservation of PDF/A versions of scholarly articles published on the blog is provided by the Thüringer Universitäts- und Landesbibliothek Jena).

66. Website: <http://opac.regesta-imperii.de/lang_en/>.

67. To our knowledge, the first series of dynamic edited volumes, published in Open Access on a blog is the series by Bauch, Martin; Döring, Karoline; Gebert, Björn, eds. Mittelalter. Interdisziplinäre Forschung und Rezeptionsgeschichte, Beihefte. 13 July 2020 <https://mittelalter.hypotheses.org/category/beihefte>. The respective editors of an individual volume of the series are responsible for the quality management, supported by the general editors of the series.

68. Hülpes, Inge; Klaes, Falko, eds. Die Stadt des Mittelalters an der Schwelle zur Frühen Neuzeit. Beiträge des interdisziplinären (Post-)Doc-Workshop des Trierer Zentrums für Mediävistik im November 2017. Leipzig-WeimarMunich: Mittelalter. Interdisziplinäre Forschung und Rezeptionsgeschichte, Beihefte, 2018. 9 March 2020 <https://web.archive.org/web/20200309144603/https://mittelalter.hypotheses.org/19200>.

69. Eckhart, Pia. “Oftmals durch den truck aus gangen oder: Eine methodische Perspektive zur Gruppierung und Interpretation gedruckter Chroniken des 16. Jahrhunderts". Mittelalter. Interdisziplinäre Forschung und Rezeptionsgeschichte, 2 (2019): 238-253. 8 October 2019 <https://www.doi.org/10.26012/ mittelalter-22513>. 
Furthermore, the German national library (Deutsche Nationalbibliothek) and other national libraries etc. archive at least some blogs, by saving images of the complete blogs once or twice a year.

The quality of blog articles can be secured just like for journal articles - either by editorial review or by peer review (or no review at all). However, in contrast to e-journal software like OJS, WordPress does not provide the comfort of a technical infrastructure for an elaborate editorial workflow management. This makes it a bit more complex to manage submissions and different file versions of a text from preprint to final article. Mittelalterblog currently provides an editorial review, since its editors are convinced that the transparent and conjoint work, by authors and editors together, in order to improve the quality of a submission until it is ready for publication (or finally not) is more productive than a blind or double blind peer review. ${ }^{70}$ And, as Daniel Lakens points out, blogs do actually practice a transparent, Open Peer Review, since peers are able to add comments to each blog post. ${ }^{71}$ This is, of course, a post publication peer review, but research results are by the definition of science never final, because the cognitive process is never complete. ${ }^{72}$ Nevertheless, Mittelalterblog will introduce a formal Open Peer Review in conjunction with its participation in the project AMAD-Archivum Medii Aevi Digitale (see the following section on repositories).

\subsubsection{Institutional, Disciplinary, and General Repositories}

There are many options to self-archive your research outputs in Open Access repositories. These repositories can be institutional, disciplinary, or general repositories. Storing your research outputs in a repository has many benefits: it helps to maximize the accessibility und usability of your works, thus boosting their impact and citations. All Open Access repositories, whether institutional, discipline specific, or general are committed to Openness and re-use of data and guarantee long-term preservation and are non-profit. ${ }^{73}$

Today, many universities and other academic institutions maintain document servers or 'institutional repositories' that allow their members to deposit publications. ${ }^{74}$ Usually, every deposit receives a persistent identifier and is guaranteed

\footnotetext{
70. Gebert, Björn; Beek, Lena van. “Wissenschaftsblogs als zeitgemäße Publikationsmedien: Das Beispiel Mittelalter. Interdisziplinäre Forschung und Rezeptionsgeschichte". Mitteilungen des Deutschen Germanistenverbandes, 66/3 (2019): 275. 8 October 2019 <https://doi.org/10.14220/mdge.2019.66.3.273>.

71. Lakens, Daniel. "Five reasons blog posts are of higher scientific quality than journal articles". The 20\% Statistician. 14 April 2017. 19 September 2019 <https://web.archive.org/web/20190919133851/http:// daniellakens.blogspot.com/2017/04/five-reasons-blog-posts-are-of-higher.html>.

72. Gebert, Björn. "Soll ich oder soll ich nicht?...": 46.

73. "Open-access repository". Wikipedia: The Free Encyclopedia, 20 June 2018. Wikimedia Foundation. 29 July 2019 <https://web.archive.org/web/20190729143207/https://en.wikipedia.org/w/index. php?title=Open-access_repository\&oldid=846693075>.

74. An example is TUprints, the institutional repository of the Technische Universität Darmstadt. Website: $<$ https://tuprints.ulb.tu-darmstadt.de>.
} 
long-term preservation. Institutional document servers are 'universal repositories' - since they usually cover a wide range of different academic disciplines, just like the university or research institution that provides the repository.

If your institution does not provide a suitable repository or if you wish to lend your research results more visibility within your field, you may opt for a disciplinary repository. 'Disciplinary repositories' contain publications of one or several related disciplines. The oldest disciplinary repository is arXiv, a repository for physics, mathematics, computer science, and some other disciplines, founded in 1991. Although the purpose of arXiv is to archive preprints (hence its frequent denomination as preprint server), not reviewed articles, OpenDOAR (Directory of Open Access Repositories) lists arXiv as disciplinary repository —and rightly so, since scholars in fast moving disciplines increasingly seem to use and cite preprints rather than wait for the peer reviewed version in a journal. ${ }^{75}$ In recent years, the number of disciplinary repositories has grown extensively and currently OpenDOAR lists 130 disciplinary repositories for the Humanities.

Three repositories are explicitly intended as repositories for Medieval Studies. The first one is RM Open Archive, ${ }^{76}$ created in 2010/11 but based on a predecessor from the year 2000. It contains about 4.500 full text publications, most of them published elsewhere before. The second one is AMAD-Archivum Medii Aevi Digitale, which will be launched probably in 2020. ${ }^{77}$ The project AMAD started in October 2018 and is funded by the German Research Foundation (DFG) ${ }^{78}$ The third is BodoArXiv (Open Repository of Medieval Studies), ${ }^{79}$ a newly founded preprint server for Medieval Studies (2019). A more general repository for the Humanities is Humanities Commons. ${ }^{80}$ Also HAL ${ }^{81}$ and Zenodo, ${ }^{82}$ two general repositories, are good places for sharing your work. OpenDOAR (Directory of Open Access Repositories) will help you to find the most suitable repository for your work.

While repositories are typically associated with the Green Road to Open Access (see 2.3.3), that is for self-archiving publications previously published in a journal, they increasingly seem to become platforms for primary Open Access publications. This is true for institutional repositories, but also (or even more) for disciplinary ones. AMAD-Archivum Medii Aevi Digitale will not only offer the possibility to deposit Green Open Access publications but also to publish Open Access books and articles

75. Aman, Valeria. The potential of preprints to accelerate scholarly communication: A bibliometric analysis based on selected journals. Berlin: Humboldt-Universität zu Berlin (MA Dissertation), 2013. 8 October 2019 $<$ https://arxiv.org/abs/1306.4856>.

76. Website: <http://www.rm.unina.it>.

77. Website: <https://www.amad.org>.

78. Döring, Karoline. "Archivum Medii Aevi Digitale. Mediävistisches Fachrepositorium und Wissenschaftsblog (AMAD): Projektbeschreibung und Projektziele". Mittelalter. Interdisziplinäre Forschung und Rezeptionsgeschichte. 19 December 2018. 5 October 2019 <https://web.archive.org/ web/20191005163806/https://mittelalter.hypotheses.org/19022>.

79. Website: <https://osf.io/preprints/bodoarxiv>.

80. Website: <https://hcommons.org>.

81. Website: <https://hal.archives-ouvertes.fr>.

82. Website: <https://zenodo.org >. 
without publications fees or article processing charges (= Diamond Open Access). While articles will have to run through an Open Peer Review, which is currently planned to be realized on Mittelalterblog, the quality of books is ensured by either the editors of an edited volume or a series, or by the supervisors a dissertation. ${ }^{83}$

\subsection{Open Research Data}

Besides articles and books, the "Berlin Declaration on Open Access to Knowledge in the Sciences and Humanities" also mentions research data that should be made available in Open Access: "Open Access contributions include original scientific research results, raw data and metadata, source materials, digital representations of pictorial and graphical materials and scholarly multimedia material" ${ }^{84}$ Open Access to research data is often referred to as Open Data.

Most researchers in the Humanities usually never use the word data in connection to their research workflow. For example, medievalists talk about their 'sources', 'research materials', or more specifically, 'manuscripts', 'texts', 'pictures', etc. These research materials are - generally speaking - research data. One of the more concise definitions of research data in the Humanities is the following definition:

DARIAH-DE understands all those sources / materials and results collected, written, described and / or evaluated in the context of a research and research question in the field of human and cultural sciences, and in machine-readable form for the purpose of archiving, citation and for further processing..$^{85}$

Though research data can be analogue and digital, in this article we will be mainly concerned with digital research data.

Providing Open Access to research data (incl. metadata) means their online publication for access and reuse by others. Some processes and practices around the publication of research data differ slightly from Open Access to articles and books, making it a more challenging, but equally rewarding process. Because arts and humanities research data are expensive goods (think of the costs for digitization, transcription, enrichment with metadata such as provenance etc.), they should be available broadly in a sustainable environment for (re)use. Thus, a heightened awareness for the role of research data in humanities research workflows and for the possibilities of opening data up in ways that are meaningful for others will benefit all stakeholders, especially individual researchers. By sharing research data

83. These project details are not yet published, but are based on the insight of one of the authors of this article: Björn Gebert was one of the initiators of the project, co-authored the text of the funding application, and is now a member of the project group.

84. "Berlin Declaration...".

85. "Research Data in the Context of DARIAH-DE". Digitale Forschungsinfrastruktur für die Geistes-und Kulturwissenschaften. Niedersächsische Staats-und Universitätsbibliothek Göttingen. 29 July $2019<$ https:// web.archive.org/web/20190729120334/https://de.dariah.eu/en/weiterfuhrende-informationen>. 
widely, and not only the final publications resulting from it, researchers may gain a faster dissemination of their results and they will work together with the wider community on the higher goal of easier access to all kinds of materials for all.

The following paragraphs will provide readers from the Humanities with a better understanding of good research data practices, that is key aspects involved in the production of reusable and interoperable research data and where to store and how to share them. ${ }^{86}$

First of all, it is necessary to understand that not all research data can be published in Open Access. Especially in cases of issues related to privacy (as in the case of sensitive data) and copyright (if no permission to publish the data can be obtained) exemptions may be applied. The underlying principle is making data 'as open as possible and as closed as necessary'. The FAIR Data Principles acknowledge this fact and underline machine-readability and interoperability as basic requirements for most computational applications. The acronym FAIR stands for: Findable, Accessible, Interoperable, and Reusable. ${ }^{87}$ FAIR data are in short datasets that are accessible for research, well-documented using standards, and available in interoperable formats. Data can be FAIR even if only the metadata, that is the data that describe the dataset, are publicly available and special permissions are needed to view the entire dataset.

An important factor for interoperable, machine-readable (meta)data is the use of standards. The more standardized data are being produced, described, processed, and published, the more interoperable and reusable they are, especially for automatic processing. Standards are well-documented methods and procedures that are broadly accepted in research communities (and beyond). The standards that are used by individual research communities can vary greatly, as they depend on research materials and methods. Widely accepted discipline specific standards relevant for Medieval Studies are for example: the guidelines of the TEI (Text Encoding Initiative), ${ }^{88}$ CEI (Charter Encoding Initiative), ${ }^{89}$ IIIF (International Interoperability

86. Wuttke, Ulrike. "“Here be dragons": Open Access to research data in the Humanities". Ulrike Wuttke. 9 April 2019. 12 August 2019 <https://web.archive.org/web/20190812122308/https://ulrikewuttke. wordpress.com/2019/04/09/open-data-humanities>; O'Donnell, Daniel Paul. "The bird in hand: Humanities research data in the age of Open Data", Digital Science Report. The State of Open Data. A selection of analyses and articles about open data, curated by Figshare. London: Digital Science, 2016: 38-39 <http://doi. org/10.5281/zenodo.1470822>.

87. "FAIR principles...". For examples from historical research and archaeology, see Erdmann, Christopher; Simons, Natasha; Otsuji, Reid; Labou, Stephanie; Johnson, Ryan; Castelao, Guilherme; Villas Boas, Bia; Lamprecht, Anna-Lena; Martinez Ortiz, Carlos; Garcia, Leyla; Kuzak, Mateusz; Martinez, Paula Andrea; Stokes, Liz; Honeyman, Tom; Wise, Sharyn; Quan, Josh; Peterson, Scott; Neeser, Amy; Karvovskaya, Lena; Lange, Otto; Witkowska, Iza; Flores, Jacques; Bradley, Fiona; Hettne, Kristina; Verhaar, Peter; Companjen, Ben; Sesink, Laurents; Schoots, Fieke; Schultes, Erik; Kaliyaperumal, Rajaram; Tóth-Czifra, Erzsébet; de Miranda Azevedo, Ricardo; Muurling, Sanne; Brown, John; Chan, Janice; Quigley, Niamh; Federer, Lisa; Joubert, Douglas; Dillman, Allissa; Wilkins, Kenneth; Chandramouliswaran, Ishwar; Navale, Vivek; Wright, Susan; Di Giorgio, Silvia; Fasemore, Mandela; Förstner, Konrad; Sauerwein, Till; Seidlmayer, Eva; Zeitlin, Ilja; Bacon, Susannah; Hannan, Katie; Ferrers, Richard; Russell, Keith; Whitmore, Deidre; Dennis, Tim. Top 10 FAIR Data $\theta$ Software Things. Toronto: Library Carpentry, 2019 $<$ http://doi.org/10.5281/zenodo.2555498>.

88. Website: <https://www.tei-c.org>.

89. Website: <https://www.cei.lmu.de>. 
Framework), ${ }^{90}$ and EAD (Encoded Archival Description).${ }^{91}$ The PARTHENOS project has collected prototypical research scenarios from several humanities communities and described the relevant standards in the form of 'recipes' in the Standardization Survival Kit (SSK). ${ }^{92}$ Another useful resource to identify relevant standards is BARTOC (Basel Register of Thesauri, Ontologies $\&$ Classifications). ${ }^{93}$

A key factor for reusable data is abundant documentation. The better your data is documented, the more valuable it becomes, either for future research, for assessing your research rigor, and even for yourself. Important parts of the documentation are descriptions of your raw and processed data (think of versioning), documentation related to the research design (think of the project proposal), tools used to process and analyze the data, source code produced for digital projects etc.

You will also need to think early about how and where you will store and publish your data during and after the project. In general it is good to look out for a data repository that is certified with the Core Trust Seal, ${ }^{94}$ which also meets many FAIR requirements such as PIDs. Noteworthy repositories for the Open Access publication of humanities research data with a rather broad scope are for example $\mathrm{HAL}^{95}$ or Zenodo. ${ }^{96}$ The re3data directory ${ }^{97}$ is a good starting point to identify a suitable repository for your research data (as well as data for reuse).

Researchers and infrastructures such as libraries, or discipline specific digital research infrastructures put huge effort in the creation and preservation of digital resources, including research data. Therefore, you should get acquainted with research data citation, for example using the DataCite recommendations. ${ }^{98}$ For this, DataCite has developed together with other partners a 'DOI Citation Formatter'.99 Data citation involves making transparent the provenance of the data you use and have derived information from, thus crediting the underlying work. With other words: If you like it, cite it!

The key to FAIR data is active research data management: Starting to think about the way you will handle, store, and publish your data before the beginning of a project and consistently throughout its whole trajectory. If the publication of research data comes only as an afterthought (if at all) at the end, in most cases it will be too late to publish the data in a meaningful way because the documentation will not be good enough, thus, leaving the data useless for reuse by others, and there will be not enough resources to properly prepare the data for publishing. There are many tools available to support data management activities of individuals

\footnotetext{
90. Website: <https://iiif.io>.

91. Website: <https://www.loc.gov/ead>.

92. Website: <http://www.parthenos-project.eu/portal/ssk-2>.

93. Website: <https://bartoc.org >.

94. Website: <https://www.coretrustseal.org >.

95. Website: <https://hal.archives-ouvertes.fr>.

96. Website: <https://zenodo.org >.

97. Website: <https://www.re3data.org>,

98. Website: <https://datacite.org >.

99. Website: <https://citation.crosscite.org>.
} 
and research groups, such as writing and maintaining a data management plan, for example DMPonline ${ }^{100}$ or RDMO. ${ }^{101}$ Research data management and the publication of research data is a task for which researchers often can make use of infrastructural support, e.g. from local, national and international research infrastructures, cultural heritage institutions, libraries, and data centers.

Knowledge of good data management practices is nowadays increasingly considered as part of researchers' skill sets and Good Scientific Practice, just as knowing how to cite correctly. Even if your funder or institution does not require you to publish your research data Open Access, keeping them as proof of your own Good Scientific Conduct is often required already. Last but not least, thinking through your research process from a data perspective will not only lead you to work more efficiently, but also more sustainable and prevent you from data loss. Horror stories of researchers losing years of research because of the failure of a harddrive or loss of a storage medium should definitely belong to the past.

\subsection{Open Science Communication in the Digital Age}

Open Science communication in the digital age is concerned with opening up science communication beyond a small circle of specialists (science inreach, or Ivory Towers) and involves new methods of communication (science outreach).$^{102}$ It makes the research process more transparent because it facilitates sharing ideasin-progress along with research results and can be considered as democratizing and empowering because it focuses on more immediate and wider appealing forms than traditional forms of academic publishing (e. g. digital storytelling). ${ }^{103}$ Non-specialist summaries of research approaches or research findings that are for example published on a blog, make research accessible to non-specialists which is needed to escape the "Ivory Tower of academia". ${ }^{104}$

The personal gains of practicing Open Science Communication can be manifold: skills development, career enhancement, research quality and impact, personal $\&$ institutional profile, influence and networking chances, forming new

100. Website: <http://www.dcc.ac.uk/dmponline>.

101. Website: <https://rdmorganiser.github.io>.

102. Raschle, Nora Maria. "The story of Science Communication". We Are All Born a Scientist. 9 March $2020<$ https://web.archive.org/web/20200309124626/https://bornascientist.com/2018/10/08/thestory-of-science-communication>; Dernbach, Beatrice; Kleiner, Christian; Münder, Herbert. Handbuch Wissenschaftskommunikation. Wiesbaden: Springer, 2012.

103. Byrne, Wendy. "What is digital storytelling and what has it got to do with cultural heritage?" Europeana Pro. 6 August 2019. 12 August 2019 <https://web.archive.org/web/20190812140423/https:// pro.europeana.eu/post/what-is-digital-storytelling-and-what-has-it-got-to-do-with-cultural-heritage $>$.

104. For a good introduction for science communication (even though mainly written for scientists, the information in this booklet is also relevant for humanists), see Carrada, Giovanni. Communicating science: "A scientist's survival kit". Brussels: European Commission, 2006. 9 March $2020<$ https://web.archive. org/web/20200309125206/https://www.livingknowledge.org/fileadmin/Dateien-Living-Knowledge/ Dokumente_Dateien/Toolbox/LK_C_Communicating_Science_Kit.pdf>. 
collaborations, ${ }^{105}$ and last but not least, having fun. ${ }^{106}$ If also your more traditional academic outputs (e.g. articles or books) are available Open Access, the impact of the less traditional forms can be even higher, because you can raise awareness for these contents which than can be immediately accessed, because one should not forget that the general public and most journalists and even some politicians etc. don't generally have access to subscription content.

\subsubsection{How to get started}

Individual researchers keen on engaging with Open Science Communication will need to decide for themselves, which communication channels and tools are the most suitable for their aims. The final choice will depend on the prospective target groups. If your main target group is well known for not being active on Twitter, all your efforts on Twitter will be a waste of time and you will need to focus on alternative channels instead. Before you start, you need to be aware of possible drawbacks of getting involved in Open Science Communication (time commitment, privacy issues, and prejudices) and then act strategically. It might be quite useful to research a bit into formats that attract your attention, get a social media training, or a training in journalistic writing to help you get going. And sometimes you will need a little time to experiment until you find a format that suits you. Just be aware that writing for a broader audience means to know how to gather the audience's attention. You need to tell an engaging story and find your own voice that will be different from traditional formats. ${ }^{107}$ Digital formats can be great advantages to help telling these stories and mixing multimedia content with your writing can be fun. In the following, you will find some possibilities of Open Science Communication in the digital age, illustrated with examples from Medieval Studies wherever possible. This overview is far from being exhaustive and the examples are intended as 'appetizers' ${ }^{108}$

\footnotetext{
105. Raschle, Nora Maria. “The story..."; Geu, Susanne. “Sichtbarkeit im Netz: Vom analogen Wissenschaftler zum Online Scientist". Helmholtz Zentrum für Infectionsforschung. 2019. 12 August 2019 <https://web.archive.org/web/20190812135234/https://www.helmholtz-hzi.de/de/aktuelles/thema/ sichtbarkeit-im-netz-vom-analogen-wissenschaftler-zum-online-scientist>.

106. For the social media success story of a historian, see Strasdin, Kate. "Insta-Research: Social media and the historian". Historical Transactions. 23 July 2019. Royal Historical Society. 12 August $2019<$ https://web.archive. org/web/20190812135402/https://blog.royalhistsoc.org/2019/07/23/insta-research-kate-strasdin>.

107. See Carrada, Giovanni. Communicating science...: 29-33.

108. For example, the German portal Wissenschaftskommunikation lists more than 100 scientific communication formats. Not all of them are digital; they range from an "adults-only-night at a museum" to "Scientific Puppet Theater": "Finden Sie hier die passenden Formate für Ihre Wissenschaftkommunikation". Wissenschaftskommunikation. Wissenschaft im Dialog-Nationalen Institut für Wissenschaftskommunikation-Karlsruhen Institut für Technologie. 9 March $2020<$ https://web. archive.org/web/20200309125702/https://www.wissenschaftskommunikation.de/formate>.
} 


\subsubsection{Blogs}

Blogs enable researchers not only to publish their thoughts quickly and easily and without a limitation of the word count, but also to share them with a wider audience; an audience consisting of scholars, interested non-academics, and (potential) funders as well (see also 4.1.2)! Furthermore, blogs are also low-threshold, less formal media for discussions and exchange of thoughts between colleagues and with the public. They also help to increase the visibility of the research of a scholar, to document his or her scholarly activities, or even to 'occupy' a topic. ${ }^{109}$ Many medievalists already maintain research blogs. A few examples have to suffice here: Turbulent Priests by Charles West, ${ }^{110}$ Le manuscrit médiéval The Medieval Manuscript by Jean Luc Deuffic, ${ }^{111}$ and The Public Medievalist by Paul B. Sturtevant, Shiloh Carroll and others. ${ }^{112}$ Dozens of other medievalists' blogs can be found in the left column of another blog already mentioned above: Mittelalter. Interdisziplinäre Forschung und Rezeptionsgeschichte. ${ }^{113}$

\subsubsection{Social Media}

Social media networks (such as Twitter, Facebook, and Instagram) play an important role for Open Science Communication in the Digital Age. A considerable number of academics prefer Twitter ${ }^{114}$ for professional activities and to keep Facebook and Instagram for more personal content. Those networks can help researchers to communicate their research to a broader audience, ${ }^{115}$ to keep track of recent developments (such as Calls for Papers and Articles, conference announcements, or funding opportunities), and even provide a career boost. Despite these advantages, there are some prejudices against social media in academia. Critics consider them as a waste of time or claim that this kind of content has in general inferior quality.

\footnotetext{
109. The results of a recent survey amongst scholars for more reasons for academic blogging: König, Mareike. "Strategische Kommunikation: wie Geisteswissenschaftler*innen bloggen. Ergebnisse der Umfrage bei de.hypotheses." Redaktionsblog. 6 June 2019. 5 October 2019 <https://web.archive.org/ web/20191005170248/https://redaktionsblog.hypotheses.org/4246>.

110. Website: <http://turbulentpriests.group.shef.ac.uk>.

111. Website: <http://pecia.blog.tudchentil.org >.

112. Website: <https://www.publicmedievalist.com>.

113. Website: <https://mittelalter.hypotheses.org $>$.

114. For a good introduction to Twitter, Scoble, Jojo. "Twitter for academics". The Online Academic. 12 August 2019 <https://web.archive.org/web/20180625220422/https://onlineacademic.wordpress.com/ social-media-for-academics/twitter-for-academics $>$.

115. Research has shown the potential of Twitter to disseminate scientific information widely, especially after individuals have reached a threshold of more than 1000 followers. Côté, Isabelle M.; Darling, Emily S. "Scientists on Twitter: Preaching to the choir or singing from the rooftops". FACETS, 3/1 (2018): 682$694<$ https://doi.org/10.1139/facets-2018-0002>. The same study also reports disciplinary differences in the use of Twitter, for example, that researchers in the Digital Humanities tweeted the most.
} 
However, using diverse communication channels including social media add up to the general academic skill set (e.g. writing skills, digital skills) and unlike simply putting content online on a static website, engaging in social networks has the advantage of being a two-way communication (bidirectional), opening up new forms of networking and collaboration. Researchers can engage with their loose social media network to find collaborative solutions to problems (as a form of using the wisdom of the crowd, \#followerpower) and engage in peer-to-peer review. If social media activities are strategically combined with other forms of Open Science Communication, such as blogging, podcasts, and videos, they can boost individual researchers' impact and career, because they provide possibilities to show individual areas of expertise and to form professional networks. It may lead to invitations as guest speakers for non-academic events or draw the attention of the media. ${ }^{116}$ And if posting content about cats can positively contribute to your visibility as a researcher and spread your research findings, as the book historian Erik Kwakkel has shown on Twitter, ${ }^{117}$ why shouldn't you give it a try?

\subsubsection{Videos and Podcasts}

Audiovisual formats such as videos and podcasts increasingly become interesting for science communication, especially because they have become cheap and easy to produce and distribute, making them attractive for institutions and individual researchers to use them in order to reach (new) audiences.

On the popular American video-sharing platform YouTube ${ }^{118}$ you can find a great variety of materials related to Medieval Studies, short clips, ${ }^{119}$ longer movies, ${ }^{120}$ or whole channels dedicated to teaching basic knowledge about the Middle Ages (in German). ${ }^{121}$ But also independent institutional platforms ${ }^{122}$ are being used for hosting audiovisual materials. Even if you are not a professional moviemaker, nowadays

\footnotetext{
116. Amongst the answers given to Dan Quintana (@dsqintana)why people use Twitter were: peer-topeer learning network, building a network with people who share the same interests and exchange ideas, discover new contents, discuss subject related issues and academia in general, networking, collaborations, remote attending in conferences by following the conference hashtag (\#). The conversation on Twitter (retrieved 8 October 2019): <https://twitter.com/dsquintana/status/1080399585535758336>.

117. Kwakkel's famous “cat-tweet” (retrieved 8 October 2019): <https://twitter.com/erik_kwakkel/ status/251349772856868864>.

118. Website: <https://youtube.com>.

119. For example, the short clip Stanford student studies the monstrous feminine in medieval literature (retrieved 5 October 2019): <https://www.youtube.com/watch?v=XQTd5aKPF9g>.

120. For example, the movie Tremulous hand: Handwriting and neurological disorders, modern and medieval (retrieved 5 October 2019): <https://www.youtube.com/watch?v=5PxQHmCnQrw>.

121. Leng, Rainer. "Channel: Grundwissen Mittelalter". YouTube. 8 October $2019<$ https://www. youtube.com/channel/UC-DSSfgRWGh5sJXoMcuYeTg>.

122. For example, the mediathek (multimedia platform) of the Bayerische Akademie der Wissenschaften, that contains short movies about its research projects, including AMAD-Archivum Medii Aevi Digitale, and recordings of events. Website: <https://badw.de/die-akademie/presse/mediathek>.
} 
you can easily get started with producing your own videos, using a digital camera and even your phone to make your first videos and edit them yourself. ${ }^{123}$ Many universities have some kind of multimedia or e-learning center/lab that provides software, hardware, and often also hands-on advice and workshops for novices to the medium.

A podcast is a "digital audio file made available on the Internet for downloading to a computer or mobile device, typically available as a series, new instalments of which can be received by subscribers automatically". ${ }^{124}$ In other words, a podcast is a recorded audio performance which is digital available on the Internet and can be listened to via desktop computers or portable devices. During the last years the thematic range of podcasts has grown enormously due to their high popularity. ${ }^{125}$ Podcasts are great for scientific topics because they are less expensive to produce than videos and people like to listen to them during their commute. They also have the potential to break down the hierarchies of a field and to amplify and democratize its voices, because they offer a platform for early career researchers, researchers into niche topics, marginalized communities, or for example participants of a conference, which may find it difficult to publish and get heard via traditional channels. ${ }^{126}$

A good way to start your career as a podcaster is by first contributing as a guest speaker to an established medieval podcast series, a podcast series of your home institution, or any other suitable series before considering starting your own podcast. ${ }^{127}$ Examples of interesting medieval podcast (episodes) are:

- The Medieval Podcast by Danièle Cybulskie,, 128

- Episode 'Dark Age nunneries' with Steven Vanderputten (in English) for the podcast Geheugenissen (Ghent University, the podcast series Geheugenissen is mainly in Dutch), ${ }^{129}$

- Episode 'Visiting monks in the High Middle Ages' with Micol Long for Agnus: The late antique, medieval, and Byzantine podcast, ${ }^{130}$

\footnotetext{
123. For getting started with videoing the blog website, see McKee, Karen L. The Scientist Videographer. 8 October $2019<\mathrm{http}$ ://thescientistvideographer.com/wordpress $>$.

124. "Podcast". Lexiko.com. 2019. Oxford University Press-Dictionary.com. 5 October 2019 <https://web. archive.org/web/20191006111538/https://www.lexico.com/en/definition/podcast>.

125. Innes, Alison. "Blog: Finding your voice through podcasting". Society for Classical Studies. 15 May 2017. 31 July 2019 <https://web.archive.org/web/20190731182718/https://classicalstudies.org/scsblog/alison-innes/blog-finding-your-voice-through-podcasting $>$.

126. From a classics point of view, Dozier, Curtis. “Blog: Vox Populi: Podcasting and equity at the SCS Annual Meeting". Society for Classical Studies. 31 December 2018. 31 July 2019 <https://web.archive.org/ web/20190731183340/https://classicalstudies.org/node/31529>.

127. Innes, Alison. "Blog: Finding your voice..."; Gawne, Lauren. "Why podcast your research?". The RED Alert. 17 April 2018. La Trobe University. 6 October $2019<$ https://web.archive.org/web/201910061 $12858 /$ http://redalert.blogs.latrobe.edu.au/2018/04/why-podcast-your-research-lauren-gawne.html>.

128. Website: <http://themedievalpodcast.libsyn.com>.

129. Website: <https://soundcloud.com/user-711326240>.

130. Website: <https://podcasts.apple.com/us/podcast/agnus-the-late-antique-medieval-and-byzantinepodcast/id1278660185>.
} 
- Episode 'Ghostly geographies: In search of medieval Swansea today' with Catherine Clarke for the podcast of the "Institute of Historical Research, University of London", ${ }^{131}$

- Episode 'Witchcraft and Open Science' with Rune Blix Hagen for the podcast Open Science Talk of the University Library at the arctic University of Norway. ${ }^{132}$

The advantages of podcasts (low level production and publication) brings with them the disadvantage for prospective audiences that there is no centralized place to keep track of them except some grass-root, community curated lists of podcasts. You can search for interesting content via podcast services and platforms such as iTunes $^{133}$ or SoundCloud. ${ }^{134}$

As YouTube or podcast services are no long-term repositories, we advise that you also store your valuable content in an Open Access repository (see 4.1.3). This not only avoids its loss, but also has the advantages of providing better access for users with bad Internet connections (they can download your content and view it offline), and even aid its further distribution and findability. Always add rich metadata to your content, like who created it, what is it about, a link to your website, and most importantly an open license which clearly indicates the terms of reuse (see 2.3).

\subsubsection{Wikipedia, other Formats and Approaches, Discovery}

As already mentioned above, there are literally hundreds of possibilities of Open Science Communication. Another good practice we would like to mention here is to spread your knowledge and research outcomes by contributing to the free online encyclopedia Wikipedia ${ }^{135}$ and providing links to your (Open Access) publications and data. This is a win-win situation, as citations of published works manifest Wikipedia's credibility and you get to promote your works. Also educational activities such as practical workshops that include the public, webinars (free online seminars) or online courses on medieval topics are exciting channels to experiment with. Medieval topics often have great potentials for engagement with the broader public. Some research and outreach activities are especially designed to involve broader groups than subject experts alone, or have special public strands for engagement with the broader public. These endeavors are commonly referred to as Public History or Public Humanities ${ }^{136}$ and have overlaps with Citizen Science. ${ }^{137}$

Last, but not least, Open Access articles, blog posts, tutorials, podcasts, and other forms of scholarly communication are scattered around the Internet. Because of

131. Website: <https://www.history.ac.uk/search-podcasts>.

132. Website: <https://site.uit.no/ub/2019/07/31/witchcraft-and-open-science>.

133. Website: <https://www.apple.com/itunes>.

134. Website: <https://soundcloud.com>.

135. Website: <https://www.wikipedia.org>.

136. Cauvin, Thomas. Public History: A textbook of practice. New York: Routledge, 2016.

137. Hecker, Susanne; Haklay, Muki; Bowser, Anne; Makuch, Zen; Vogel, Johannes; Bonn, Aletta, eds. Citizen Science... 
their rapid publication dynamic, they are (still) rarely to be found via established bibliographic tools and library systems. This makes it difficult for individual researchers to identify relevant, high quality information resources. As a means to fill this gap, OpenMethods, ${ }^{138}$ a metablog that highlights and promotes especially Open Access content in the field of Digital Humanities Methods and Tools, including Digital Medieval Studies, has been founded in order to help researchers to navigate the enormous amount of material available online. The OpenMethods 'metablog approach' entails that the Editorial Team selects already published content to be highlighted on the OpenMethods metablog, a dedicated online platform. The editors select, curate and categorize the content —which is also proposed by Community Volunteers - using TaDiRAH (Taxonomy of Digital Research Activities in the Humanities) $)^{139}$ as well as conduct a quality check in order to make it easier to identify interesting high quality resources on Digital methods and tools. A different approach to identifying relevant Open Access resources is the experimental visualization of the BASE content via Open Knowledge Maps. ${ }^{140}$

\section{Challenges \& Take Away Messages}

Although progress is being made, the uptake of Open Scholarship concepts and practices is advancing only slowly. In 2019 science still seems far from being open by default. For various reasons it is difficult to measure progress in numbers, but for example scholarly literature is, despite growing interest in Open Access to scholarly literature and almost 20 years of campaigning and relentless efforts, not yet in majority Open Access. ${ }^{141}$

The list of (perceived) barriers and obstacles that can be encountered in literature and discussions with researchers is long, repeated topics are: lack of awareness, lack of (suitable) services and tools, the need for training (theory $\&$ upskilling), lack of incentives $\delta$ rewards, and fears, e. g. doubts about negative effects on career (scooping etc.). ${ }^{142}$ During the 2018 Carmen workshop we also discussed barriers and obstacles to Open Scholarship with the participants, below the summary of the discussion results is cited:

\section{- Awareness Raising:}

- Authors need to be aware that there are alternatives to Closed Access (Gold Open Access as in immediate Open Access, Green Open Access as in

\footnotetext{
138. Website: <https://openmethods.dariah.eu>.

139. Website: <http://tadirah.dariah.eu/vocab/index.php>.

140. Website: <https://openknowledgemaps.org>.

141. Piwowar, Heather; Priem, Jason; Larivière, Vincent; Alperin, Juan Pablo; Matthias, Lisa; Norlander, Bree; Farley, Ashley; West, Jevin; Haustein, Stefanie. "The state of OA...".

142. Eynden, Veerle van den; Bishop, Libby. Sowing the seed: Incentives and motivations for sharing research data, a researcher's perspective. Bristol: Knowledge Exchange, $2014<$ http://repository.jisc.ac.uk/5662/1/ KE_report-incentives-for-sharing-researchdata.pdf $>$.
} 
publication of preprints, postprints, authorized version, maybe after embargo period) for articles and monographs. ${ }^{143}$

\section{- Education:}

- Authors need to know their rights when engaging with publishers (Green Open Access, Sparc addendum, etc.)

- OA seems to add an extra challenge to teaching students which sources are reliable $\left(\right.$ Peer Reviewed $=$ good quality),${ }^{144}$ if the digitally published material is more diverse (and not always peer reviewed), one has to teach digital literacy skills \& (digital) source criticism, which one may in fact consider as one major skill of a good historian anyway

- Need for a Paradigm Change within the Scholarly Community:

- We need to be more aware and critically discuss where the prestige comes from. The name of the journal or the name of the publisher? Maybe open peer review could offer a solution here? Should researchers still support closed journals, series?

- Often OA publications have by default a low reputation and are perceived as less valuable scholarship although they are often also prone to strict peer review (which is often not recognised); also digital publishing in general has less prestige

- many prestigious publishers do not do OA (or at very high cost)

- It would be unfair to put ECR [=Early Career Researchers, note from the authors] at risk for their career to oblige them to do so, even though there is a "Kamikaze Open Access School", but...the established researchers should promote OA wherever they can ("Senior scholars should pave the way")

\section{- Policy Making}

- Choosing Open Access or Open Scholarly Methods does often not count for tenure

\section{- Practical Solutions:}

- OA for books is important for the humanities, we need good hybrid publication models (e.g. OA published by the library/publisher, book printed on demand)

- at the moment journals often bring in the revenue for scholarly societies, to make them Open Access poses a problem for the sustainability of the society

- Article Processing Charges are often very high (besides this being a problem of the commercialised system), even low APCs can cause a problem (support scholars to pay APCs). ${ }^{145}$

\footnotetext{
143. Community driven primary Open Access publications (Diamond Open Access) are an alternative to APC-based primary Open Access (Gold Open Access) offered by commercial publishers.

144. However, Peer Review — at least Blind and Double Blind Peer Review—seems to be more controversial than ever today. For a summary of criticism, see Abambres, Miguel; Salloom, Tony; Beganovic, Nejra; Dojka, Rafał, Roncallo-Dow, Sergio; Verma, Tarun, Takhar, Sukhraj. "Bye bye peer-reviewed publishing". HAL: archives-ouvertes. 15 December 2019. Centre pour la Communication Scientifique Directe. 9 March $2020<$ https://hal.archives-ouvertes.fr/hal-02114531v8>.

145. Fortunately for authors, there are already many universities and research foundations that fund Open Access publications by their members or awardees under certain conditions. A good starting point
} 
- Open Peer Review could change the way we do research and evaluate research, but how to organize it practically". ${ }^{146}$

Many of the fears related to negative effects of Open Scholarship methods mentioned above stem from disciplinary traditions and the increasing role of research metrics. Especially in the Humanities, the prestige of the journal or the publisher plays a huge role. Because many of the most prestigious journals and publishers in the Humanities are not (yet) fully transitioned to Open Access or are moving towards Gold Open Access, still commercial closed or hybrid business models of one of the global big players are favored, despite available less expensive Open Access alternatives. Being obliged to publish Open Access (as in the case of Plan S) is often perceived as a thread to the ability to build an international reputation and other research results such as data or tools, or activities like reviewing, teaching, research dissemination and communication did traditionally not play a significant role to build a scientific track record for tenure.

From the various reasons that are slowing down the open transformation, especially individual researchers' concerns about their career prospects have to be taken seriously as practicing Open Science should not harm anyone. Good news is that the tide is slowly changing. Initiatives like 'The San Francisco Declaration on Research Assessment (DORA)'147 or the 'Jussieu Call for Open Science and Bibliodiversity ${ }^{148}$ are demanding and supporting a more diverse recognition and publication system and business models that do not involve any payments neither for authors nor for readers. These initiatives —which are gaining international support from various research institutions- are helping to prepare the soil for an open research ecosystem, which is prompted and required to boot the digital transformation of research.

\section{Key Resources}

Often your university or institutional library can provide you with more information about Open Access policies, initiatives and services in place at your institution, e.g. a University Press or an institutional repository with at least some Open Access contents. In this section we would like to share a commented list of useful resources for medievalists in the digital age. This list does by no means claim to be exhaustive and it contains only non-profit resources. Within each section the items are ordered alphabetically. ${ }^{149}$

\footnotetext{
for exploring the possibilities are your institution's Open Access websites and contacting your Open Access officer (for instace, at your library).

146. Wuttke, Ulrike. "Let's talk...".

147. Website: <https://sfdora.org >.

148. Website: <https://jussieucall.org/jussieu-call>.

149. The editors of Imago Temporis. Medium Aevum were so kind to allow us to bring a so-called living version of the following list online in 2020. The living version may differ from the following printed
} 


\subsection{Open Science $\theta$ Open Access (General) / Open Research Data}

BARTOC (Basel Register of Thesauri, Ontologies \& Classifications): Resource to identify relevant standards. ${ }^{150}$

Creative Commons: Information about the Creative Commons Licenses, License generator etc. ${ }^{151}$

ELDAH: The DARIAH Working Group 'Ethics and Legality in the Digital Arts and Humanities (ELDAH') is dedicated to issues such as privacy, copyright, licensing etc. and provides useful resources. ${ }^{152}$

Edmond, Jennifer; Tóth-Czifra, Erzsébet. Open Data for Humanists, A pragmatic guide. 2018. 9 March 2020 <https://halshs.archives-ouvertes.fr/halshs-02115443>.

Eve, Martin Paul. Open Access in the Humanities. Contexts, controversies and the future. Cambridge: Cambridge University Press, 2014. This discipline-specific discussion of Open Access is also available Open Access.

FOSTER: The FOSTER (Fostering the practical implementation of Open Science in Horizon 2020 and beyond) project has produced and collected (discipline) specific training materials to all areas related to Open Science and made them accessible in a online portal. ${ }^{153}$

GO FAIR: Initiative dedicated to the implementation of the FAIR data principles that offers information and training materials. ${ }^{154}$

Open-access.net: This platform provides information on Open Access and offers practical advice (German, English). ${ }^{155}$

Open Research Glossary: Glossary with a lot of information about various aspects of Open Scholarship. ${ }^{156}$

Open Science MOOC: Community sourced, co-created online course about various aspects of Open Science. ${ }^{157}$

PARTHENOS: Hollander, Hella; Morselli, Francesca; Uiterwaal, Frank; Admiraal, Femmy; Trippel, Thorsten; Di Giorgio, Sara. PARTHENOS guidelines to FAIRify data management and make data reusable. 12 August 2019. DOI: <http://doi.org/10.5281/ zenodo.3368858>.

\footnotetext{
version (updates, additional resources). Wuttke, Ulrike; Gebert, Björn. “Open Science: Key Resources for Medievalists". Mittelalter. Interdisziplinäre Forschung und Rezeptionsgeschichte. 3 May 2020. 13 October 2020 $<$ https://mittelalter.hypotheses.org/25190>.

150. Website: <https://bartoc.org >.

151. Website: <https://creativecommons.org $>$.

152. Website: <https://www.dariah.eu/activities/working-groups/ethics-and-legality-in-the-digital-artsand-humanities-eldah>.

153. Website: <https://www.fosteropenscience.eu>.

154. Website: <https://www.go-fair.org>.

155. Website: <https://open-access.net/en/germany-english>.

156. Website: <http://www.righttoresearch.org/resources/OpenResearchGlossary>.

157. Website: <https://opensciencemooc.eu>.
} 
PARTHENOS Training Suite: Training modules and resources in Digital Humanities and Infrastructures, including e.g. the module 'Manage, improve and open up your research data'. ${ }^{158}$

Tóth-Czifra, Erzsébet; Romary, Laurent. “Open Access guidelines for the Arts and Humanities: Recommendations by DARIAH". DARIAH Open, 20 February 2019. ${ }^{159}$

Suber, Peter. Open Access. Cambridge (Mass.), London: MIT Press, 2012. This seminal book on Open Access is also available Open Access (in several languages).

Wuttke, Ulrike. "Is your research future proof? Data management techniques \& tools for Digital Historians" (Training Slides). Zenodo, 2019. DOI: <http://doi. org/10.5281/zenodo.3247014>.

\subsection{Open Access Journals, Books, Repositories: Publishing $\theta$ Discovery}

AMAD (Archivum Medii Aevi Digitale): Forthcoming disciplinary repository for Medieval Studies. ${ }^{160}$

BASE (Bielefeld Academic Search Engine): Search engine for (mostly freely available) academic web resources. ${ }^{161}$

BodoArXiv: Open Access preprint server for Medieval Studies. ${ }^{162}$

DOAB: Directory of Open Access Books. ${ }^{163}$

DOAJ: Directory of Open Access Journals. ${ }^{164}$

Internet Archive: Database for free digitized books and other resources. ${ }^{165}$

ISIDORE: Search engine for electronic publications in the Humanities and Social Sciences. ${ }^{166}$

HAL: Open archive for scholarly documents from all academic fields. ${ }^{167}$

Humanities Commons: A disciplinary Open Access repository for the Humanities. ${ }^{168}$

\footnotetext{
158. Website: <https://training.parthenos-project.eu>. hypotheses.org/390>.

160. Website: <https://www.amad.org>.

161. Website: <https://www.base-search.net/index.php>.

162. Website: <https://osf.io/preprints/bodoarxiv>.

163. Website: <https://www.doabooks.org>.

164. Website: <https://doaj.org >.

165. Website: <https://archive.org >.

166. Website: <https://isidore.science>.

167. Website: <https://hal.archives-ouvertes.fr>.

168. Website: <https://hcommons.org>.
}

159. Laurent Romary, Erzsébet Tóth-Czifra. “Open Access guidelines for the arts and humanities: recommendations by DARIAH". DARIAH Open: Open scholarly practices in the arts and humanities. 20 February 2019. 6 October 2019 <https://web.archive.org/web/20191006212315/https://dariahopen. 
Publishers of OA Books: Community sourced list, part of the Open Access Directory $^{169}$

ORCID: Register here to get your Open Researcher and Contributor ID and start building your open researcher profile. ${ }^{170}$

OLH (Open Library of Humanities): Non-commercial initiative that offers a variety of journals. ${ }^{171}$

OpenDOAR: Directory of Open Access Repositories. ${ }^{172}$

OpenEdition: OpenEdition brings together platforms for electronic Open Access journals, books, blogs, and events announcements. ${ }^{173}$

Open Access Digital Theological Library: Virtual library for digital resources in Theology, Religious Studies and related subjects. ${ }^{174}$

Open Access Journals relevant for Medieval Studies, Dutch Studies, or Digital Humanities: List collected by Ulrike Wuttke. ${ }^{175}$

OpenMethods: Metablog that highlights and promotes especially Open Access content in the field of Digital Humanities Methods and Tools, including Digital Medieval Studies. ${ }^{176}$

re3data: Global registry of research data repositories. ${ }^{177}$

RI Opac: The major freely accessible literature database for Medieval Studies with more than 2.3 million titles. ${ }^{178}$

RM Open Archive: Repository for free accessible publications in the field of Medieval Studies. ${ }^{179}$

SHERPA/RoMEO: Database with information about publisher copyright and self-archiving policies. ${ }^{180}$

Think.Check.Submit: Initiative to assess the trustworthiness of Open Access journals. ${ }^{181}$

Unpaywall: Popular browser extension that shows immediately if an Open Access version of an article exists. ${ }^{182}$

Zenodo: General (catch-all) repository funded by CERN and OpenAIRE. ${ }^{183}$

169. Website:<http://oad.simmons.edu/oadwiki/index.php?title=Publishers_of_OA_books6oldid=27763>.
170. Website: <https://orcid.org>.
171. Website: <https://www.openlibhums.org>.
172. Website: <http://v2.sherpa.ac.uk/opendoar>.
173. Website: <https://www.openedition.org>.
174. Website: <http://oadtl.org>.
175. Website: <https://ulrikewuttke.wordpress.com/links>.
176. Website: <https://openmethods.dariah.eu>.
177. Website: <https://www.re3data.org>.
178. Website: <http://opac.regesta-imperii.de/lang_en/>.
179. Website: <http://www.rmoa.unina.it>.
180. Website: <http://sherpa.ac.uk/romeo/index.php>.
181. Website: <https://thinkchecksubmit.org>.
182. Website: <https://unpaywall.org>.
183. Website: <https://zenodo.org>. 


\subsection{Science Communication, (Academic) Blogs, Social Media, Podcasts $\theta$ Videoing}

Carrada, Giovanni. Communicating science: "A scientist's survival kit". 2006. ${ }^{184}$

Duke, Monika. "How to write a Lay Summary". DCC How-to Guides, 2012. ${ }^{185}$

Gawne, Lauren. "Why podcast your research?". The RED Alert, 17.04.2018. Short general introduction to academic podcasting. ${ }^{186}$

Hypotheses: Platform for academic blogs. ${ }^{187}$

Innes, Alison. "Blog: Finding your Voice through Podcasting". Classical Studies, 15 May 2017: Short general introduction to podcasting. ${ }^{188}$

König, Mareike. “Twitter in der Wissenschaft: Ein Leitfaden für Historiker/ innen." Digital Humanities am DHIP, 28 April 2015: Guide for historians on how and why to use Twitter (in German). ${ }^{189}$

Mittelalter. Interdisziplinäre Forschung und Rezeptionsgeschichte (= Mittelalterblog). Academic blog that has become a popular platform for Open Access publications in the field of Medieval Studies (German, English). ${ }^{190}$

Scoble, Jojo. "Twitter for Academics" The Online Academic: General introduction to Twitter for academics. ${ }^{191}$

Stevenson, Ana. "How can historians best use Twitter?" Australian Women's History Network, 20 July 2016: Guide for historians on how and why to use Twitter. ${ }^{192}$

184. Carrada, Giovanni. Communicating science: "A scientist's survival kit". Brussels: European Commission, 2006. 9 March 2020 <https://web.archive.org/web/20200309125206/https://www.livingknowledge. org/fileadmin/Dateien-Living-Knowledge/Dokumente_Dateien/Toolbox/LK_C_Communicating_ Science_Kit.pdf>.

185. Duke, Monika. "How to Write a Lay Summary". DCC. How-to-Guides. 2012. Digital Curation Centre. 7 October 2019 <https://web.archive.org/web/20191007202108/http://www.dcc.ac.uk/resources/howguides/write-lay-summary>.

186. Gawne, Lauren. "Why podcast your research?". The RED Alert. 17 April 2018. La Trobe University. 6 October 2019 <https://web.archive.org/web/20191006112858/http://redalert.blogs.latrobe.edu. au/2018/04/why-podcast-your-research-lauren-gawne.html>.

187. Website: <https://hypotheses.org >.

188. Innes, Alison. "Blog: Finding your voice through podcasting". Society for Classical Studies. 15 May 2017. 31 July 2019 <https://web.archive.org/web/20190731182718/https://classicalstudies.org/scsblog/alison-innes/blog-finding-your-voice-through-podcasting $>$.

189. König, Mareike. "Twitter in der Wissenschaft: Eit Leitfaden für Historiker/innen”. Digital Humanities am DHIP. 21 August 2012. Deutschen Historischen Instituts Paris. 7 October 2019. <https://web.archive. org/web/20191007200233/https://dhdhi.hypotheses.org/1072>.

190. See note 60 .

191. Scoble, Jojo. "Twitter for academics". The Online Academic. 12 August 2019 <https://web.archive. org/web/20180625220422/https://onlineacademic.wordpress.com/social-media-for-academics/twitterfor-academics>.

192. Stevenson, Ana. "How can historians best use Twitter?". VIDA. Blog of the Australian Women's History Network. 20 July 2016. Australian Women's History Network. 7 October 2019: https://web.archive.org/ web/20190325042629/http://www.auswhn.org.au/blog/can-historians-best-use-twitter. 
Ullyot, Michael. "On blogging in the Digital Humanities". Michael Ullyot, 24 February 2012: Short reflection on why and how to blog (not only) in the Digital Humanities and useful links. ${ }^{193}$

Wuttke, Ulrike. "How to make your medieval research more visible with Open Scholarship methods and tools: Workshop at CARMEN Annual Meeting Tampere University (28 August 2018) (Version 2.0)". Zenodo, 2018. DOI: <http://doi. org/10.5281/zenodo.1408007>.

\subsection{Tools $\theta$ Methods (Scientific Communication, Dissemination, Digital Humanities)}

forText: Method descriptions, text collections and tools - from digitisation and digital annotation to digitally supported interpretation and visualisation of literature (in German). ${ }^{194}$

Innovations in Scholarly Communication: Changing Research Workflows: Project by Bianca Kramer and Jeroen Bosman with a portal that presents (open) tools used in Scientific Communication. ${ }^{195}$

Konkiel, Stacy, The 30-day impact challenge: The ultimate guide to raising the profile of your research, 2015: This guide contains a quite comprehensive list of tools and methods (e.g. Twitter, Open Access, preprints, Open Peer Review), though not all of them can be truly be called open (problematic are for example commercial academic networking sites like Academia.edu or ResearchGate). ${ }^{196}$

OpenMethods: Metablog that highlights and promotes especially Open Access content in the field of Digital Humanities Methods and Tools, including Digital Medieval Studies. ${ }^{197}$

OpenUp: Portal dedicated to opening up research, look for example at the thematic section 'Dissemination' which contains for example a set of tools for innovative dissemination. ${ }^{198}$

PARTHENOS Standardization Survival Kit (SSK): Descriptions of prototypical research scenarios from several humanities communities with their relevant standards. ${ }^{199}$

193. Ullyot, Michael. “On blogging in the Digital Humanities”. Michael Ullyot. 24 February 2012. 7 October 2019 <https://web.archive.org/web/20191007201321/http://ullyot.ucalgaryblogs.ca/2012/02/24/onblogging-in-the-digital-humanities $>$.

194. Website: <https://fortext.net>.

195. Website: <https://10linnovations.wordpress.com>.

196. Konkiel, Stacy. The 30-day impact challenge. The ultimate guide to raising the profile of your research. 9 March 2020 <https://web.archive.org/web/20200309141154/http://blog.impactstory.org/wp-content/ uploads/2015/01/impact_challenge_ebook_links.pdf $>$.

197. Website: <https://openmethods.dariah.eu>.

198. Website: <https://www.openuphub.eu>.

199. Website: <http://www.parthenos-project.eu/portal/ssk-2>. 
Programming Historian: peer-reviewed tutorials that help humanists learn a wide range of digital tools, techniques, and workflows to facilitate research and teaching (also in Spanish and French). ${ }^{200}$

Tapor: TAPoR is a gateway to the tools used in Digital Humanities, esp. sophisticated text analysis and retrieval. ${ }^{201}$

\subsection{Networks}

CARMEN (Co-operative for the Advancement of Research through a Medieval European Network): While based in Europe, CARMEN reaches out to all continents to create an open and truly international platform of co-operation in the field of medieval research and teaching. ${ }^{202}$

DARIAH-EU (Digital Research Infrastructure in the Arts and Humanities): Network dedicated to enhance and support digital research and teaching in the Arts and Humanities. ${ }^{203}$

CLARIN-EU (European Research Infrastructure for Language Resources and Technology): This network makes digital language resources available to scholars, researchers, students and citizen-scientists from all disciplines, especially in the Humanities and Social Sciences. ${ }^{204}$

IFPH (International Federation for Public History): federation that encourages, promotes, and coordinates, at an international level, contacts, teaching and research in public history. ${ }^{205}$

Open Knowledge Foundation: Global non-profit organisation focused on realising Open Data's value to society by helping civil society groups access and use data to take action on social problems. ${ }^{206}$

\section{Acknowledgements}

Ulrike Wuttke would like to thank CARMEN for offering space for the 2018 workshop and the participants and especially James Smith for the vivid discussion. We would also like to thank all Open Science enthusiasts who inspired and informed our visions during various informal exchanges.

\footnotetext{
200. Website: <https://programminghistorian.org >.

201. Website: <http://tapor.ca/home>.

202. Website: <http://www.carmen-medieval.net>.

203. Website: <https://www.dariah.eu>.

204. Website: <https://www.clarin.eu>.

205. Website: <https://ifph.hypotheses.org $>$.

206. Website: <https://okfn.org >.
} 